\title{
Serum prohepcidin and other iron metabolism parameters in elderly patients with anemia of chronic disease and with iron deficiency anemia
}

\author{
Justyna Przybyszewska', Ewa Żekanowska², Kornelia Kędziora-Kornatowska ${ }^{3}$, \\ Joanna Boinska², Roman Cichon', Katarzyna Porzych ${ }^{3}$ \\ 1 Department of Nutrition and Dietetics, Nicolaus Copernicus University, Ludwik Rydygier Collegium Medicum in Bydgoszcz, Poland \\ 2 Department of Pathophysiology, Nicolaus Copernicus University, Ludwik Rydygier Collegium Medicum in Bydgoszcz, Poland \\ 3 Department and Clinic of Geriatrics, Nicolaus Copernicus University, Ludwik Rydygier Collegium Medicum in Bydgoszcz, Poland
}

\section{KEY WORDS}

anemia of chronic disease, iron deficiency anemia, prohepcidin

\section{ABSTRACT}

INTRODUCTION The diagnosis of iron deficiency anemia (IDA) in the context of the anemia of chronic disease (ACD) in elderly patients is often difficult due to the existence of many disorders. Recent studies have shown that hepcidin measurement (combined with the existing diagnostic methods) may possibly help in the differential diagnosis of IDA and ACD.

OBJECTIVES The aim of the study was to evaluate the differential diagnostic value of serum prohepcidin in elderly patients with IDA and ACD.

PATIENTS AND METHODS The study included 65 individuals aged 65 years or more: 26 patients with ACD, 13 patients with IDA, and 26 age-matched controls. Prohepcidin, ferritin, soluble transferrin receptor, erythropoietin, and interleukin 6 (IL-6) were measured using the commercially available enzyme-linked immunosorbent assay kits. Complete blood count, total iron-binding capacity (TIBC), and iron, transferrin, and C-reactive protein (CRP) levels were assayed using the standard laboratory methods.

RESULTS Prohepcidin concentrations were similar in patients with ACD $(196.59 \mathrm{ng} / \mathrm{ml})$ compared with those with IDA $(230.16 \mathrm{ng} / \mathrm{ml})(P=0.35)$. Patients with ACD had significantly lower levels of TIBC compared with those with IDA $(P<0.0001)$. Serum ferritin concentration in patients with ACD was almost 20 -fold higher compared with those observed in patients with IDA $(P<0.0001)$. CRP and IL-6 concentrations in patients with ACD were significantly higher compared with those with IDA.

CONCLUSIONS The results of the study indicate that serum prohepcidin has limited value in the differential diagnosis of IDA and ACD in elderly patients.

INTRODUCTION Anemia of chronic disease (ACD) and iron-deficiency anemia (IDA) are common hematological conditions present in elderly patients. ${ }^{1-3}$ They are a risk factor for cardiovascular diseases, contribute to fatigue, and negatively affect cognitive and physical functions as well as the quality of life. ${ }^{4}$ ACD is a typically micro- or normocytic, normochromic anemia associated with chronic infections, chronic noninfectious inflammatory diseases, and malignancies. The pathogenesis of ACD is multifactorial. It involves impaired erythropoietin-dependent erythropoiesis caused by proinflammatory cytokines (interleukin 6 [IL-6], C-reactive protein [CRP], and tumor necrosis factor- $\alpha$ ), impaired iron mobilization, and shortened red blood cell survival. ${ }^{4-8}$ IDA develops, in the most part, due to chronic blood loss from the gastrointestinal tract, caused by aspirin or other nonsteroidal anti-inflammatories, ulcers, colon cancer, or diverticulosis. ${ }^{3}$ Other causes of chronic blood loss or iron deficiency due to poor nutrition in this patient group are less likely. ${ }^{9-12}$ In the elderly population, severe IDA may also affect the production of other proteins containing $\mathrm{Fe}^{2+}$, such as cytochromes, myoglobin, catalase, and peroxidase. ${ }^{13}$ 
IDA is also frequently diagnosed in patients with chronic heart failure. ${ }^{14}$

The diagnosis of IDA within the context of ACD in elderly patients is often difficult due to the presence of multiple abnormalities. ${ }^{15}$ The diagnosis of ACD is usually made on the basis of a low serum iron concentration, low or normal total iron-binding capacity (TIBC), low transferrin saturation, and increased ferritin combined with the presence of chronic disease. The diagnosis of IDA includes measurement of serum iron, transferrin saturation, and serum ferritin. However, the reference diagnostic criteria for these parameters are not available for this population. ${ }^{16}$

The standard treatment of IDA requires the administration of iron therapy to rebuild iron stores, while the administration of iron in ACD may even worsen the underlying disease. For this reason, an accurate assay, with high specificity and sensitivity, for the differential diagnosis of ACD and IDA in elderly patients is extremely important.

In 2000, hepcidin was found to be a link between the immune system and the transport of iron to and from the storage pool. ${ }^{17,18}$ Circulating hepcidin binds to ferroportin (iron exporter present in the membrane of macrophages, hepatocytes, and enterocytes), inducing receptor-ligand internalization and lysosomal degradation in the cytoplasm. ${ }^{19,20}$ As a result, hepcidin regulates iron absorption in the small intestine as well as iron release from the reticuloendothelial macrophages. ${ }^{19,20}$ In 2002, Nicolas et al. ${ }^{21}$ discovered that the gene encoding hepcidin was regulated in response to anemia, hypoxia, and inflammation. Studies indicate that IL-6 and other inflammatory mediators may increase hepcidin concentrations in human serum through the JAK2/STAT3 signaling pathway. ${ }^{22-24}$

Elderly persons are often affected by a chronic mild proinflammatory state characterized by elevated levels of proinflammatory markers, including IL-6 and CRP. There is a hypothesis that this mild inflammatory state may cause a chronic elevation of circulating hepcidin and, consequently, develop anemia. A link between hepcidin and ACD has been shown by Fleming and Sly. ${ }^{5}$ Hepcidin assays may facilitate the diagnosis of IDA and $\mathrm{ACD}$, probably in combination with the existing diagnostic methods.

The aim of this study was to evaluate the differential diagnostic value of serum prohepcidin in different causes of anemia in elderly patients.

PATIENTS AND METHODS The study group consisted of 39 patients ( 17 men and 22 women) aged between 65 to 91 years (mean age, $78.92 \pm 8.32$ years) admitted to the Department and Clinic of Geriatrics of the Collegium Medicum in Bydgoszcz, Poland, with the diagnosis of anemia (World Health Organization definition). Based on the physical examination and such parameters as serum iron, ferritin, TIBC, and transferrin saturation (according to the algorithm proposed by Balducci) ${ }^{25}$ patients were divided into 2 subgroups: group 1 including
26 patients (67\%) with ACD, and group 2 including 13 patients (33\%) with IDA. The exclusion criteria were chronic kidney disease and cancer.

The control group consisted of 26 healthy nonobese elderly volunteers ( 11 women, 15 men) between 65 and 88 years of age (mean age, 68.46 \pm 7.47 ). The exclusion criteria were chronic inflammatory diseases, anemia, undernutrition, cancer, rheumatic disorders, inflammatory bowel diseases, endocrine diseases, and use of steroid or nonsteroidal anti-inflammatory drugs. All persons who took any vitamin and mineral supplements were also excluded from the study.

Peripheral blood samples were taken after the diagnosis of anemia had been established but prior to the administration of treatment.

All procedures in the study were approved by the local ethics committee. Informed written consent was obtained after the purpose, nature, and potential risks were explained to subjects.

Analytical methods Levels of prohepcidin were determined by a stable enzyme-linked immunosorbent assay (ELISA) (Hepcidin Prohormone ELISA, DRG Instruments GmbH, Germany). Serum iron concentrations and TIBC were measured using the Architect c8000 System (Abbott Laboratories, United States). Serum ferritin was quantified using the DRG Ferritin kit (EIA-1872, DRG International Inc., United States). Serum soluble transferrin receptor (sTfR) concentrations were examined by an ELISA (Human sTfR ELISA, BioVendor Laboratory Medicine Inc., Czech Republic). $\mathrm{CRP}$ concentrations in serum were determined using BNTMII Systems (Dade Behring, Marburg, Germany). IL-6 concentrations were determined using the IL-6 kit (Bender MedSystems $\mathrm{GmbH} \mathrm{Vi-}$ enna, Austria). Plasma erythropoietin (EPO) was determined by the EPO ELISA kit (Roche Diagnostics $\mathrm{GmbH}$, Mannheim, Germany). Complete blood cell count was analyzed using the Sysmex XE-2100 (Roche Diagnostics GmbH).

Statistical analysis All statistical analyses were performed using the Statistica 8.0 software (Stat-Soft, Cracow, Poland). The normal distribution of the variables was evaluated using the Shapiro-Wilk test. Parametric data were expressed as mean, standard deviation, minimum and maximum. Nonparametric parameters were presented by median and percentile values. An independent sample $t$ test for parametric continuous variables and the Mann-Whitney $U$ test for nonparametric continuous variables were used to compare the difference between the 2 groups of patients. The relationships between the examined parameters were determined by the Spearman's rank-order correlation. A $P$ value of less than 0.05 was considered statistically significant.

RESULTS The subgroups (ACD vs. IDA) did not differ in terms of age (TABLE 1). There were nonsignificant differences between the subgroups in the body mass index and body fat percentage 
TABLE 1 Hematological indices in patients with anemia of chronic disease and iron deficiency anemia

\begin{tabular}{|c|c|c|c|c|}
\hline \multirow[t]{2}{*}{ Parameter } & \multicolumn{2}{|c|}{ Study groups } & Control group & \multirow[t]{2}{*}{$P$} \\
\hline & $\begin{array}{l}\text { anemia of chronic disease } \\
I(n=26)\end{array}$ & $\begin{array}{l}\text { iron deficiency anemia } \\
\|(\mathrm{n}=13)\end{array}$ & $\begin{array}{l}\text { no anemia } \\
\quad \text { III }(n=26)\end{array}$ & \\
\hline age, y & $\begin{array}{l}79.78 \pm 8.27 \\
(65.83-91.33)\end{array}$ & $\begin{array}{l}79.00 \pm 8.11 \\
(62.75-91.25)\end{array}$ & $\begin{array}{l}68.46 \pm 7.47 \\
(65.17-88.33)\end{array}$ & $\begin{array}{l}\text { NS (I vs. II) } \\
\text { NS (I vs. III) } \\
\text { NS (II vs. III) }\end{array}$ \\
\hline $\mathrm{BMI}, \mathrm{kg} / \mathrm{m}^{2}$ & $\begin{array}{l}26.30 \pm 5.61 \\
(18.38-45.71)\end{array}$ & $\begin{array}{l}28.28 \pm 4.81 \\
(24.02-39.64)\end{array}$ & $\begin{array}{l}31.44 \pm 4.11 \\
(23.95-38.50)\end{array}$ & $\begin{array}{l}\text { NS (I vs. II) } \\
0.002 \text { (I vs. III) } \\
\text { NS (II vs. III) }\end{array}$ \\
\hline$\% \mathrm{FM}, \%$ & $\begin{array}{l}29.39 \pm 10.52 \\
(7.60-44.25)\end{array}$ & $\begin{array}{l}31.46 \pm 7.63 \\
(17.58-41.85)\end{array}$ & $\begin{array}{l}39.54 \pm 5.97 \\
(29.30-48.15)\end{array}$ & $\begin{array}{l}\text { NS (I vs. II) } \\
0.0008 \text { (I vs. III) } \\
0.004 \text { (II vs. III) }\end{array}$ \\
\hline $\mathrm{HGB}, \mathrm{g} / \mathrm{dl}$ & $\begin{array}{l}10.28 \pm 1.60 \\
(7.00-12.9)\end{array}$ & $\begin{array}{l}10.16 \pm 1.85 \\
(7.10-12.90)\end{array}$ & $\begin{array}{l}14.07 \pm 1.34 \\
(12.30-16.90)\end{array}$ & $\begin{array}{l}\text { NS (I vs. II) } \\
<0.0001 \text { (I vs. III) } \\
<0.0001 \text { (II vs. III) }\end{array}$ \\
\hline HCT, \% & $\begin{array}{l}32.34 \pm 4.74 \\
(22.30-40.40)\end{array}$ & $\begin{array}{l}32.98 \pm 6.38 \\
(20.90-41.70)\end{array}$ & $\begin{array}{l}42.00 \pm 3.37 \\
(36.10-50.70)\end{array}$ & $\begin{array}{l}\text { NS (I vs. II) } \\
<0.0001 \text { (I vs. III) } \\
0.0001 \text { (II vs. III) }\end{array}$ \\
\hline MCV, fl & $\begin{array}{l}91.52 \pm 4.99 \\
(81.90-99.40)\end{array}$ & $\begin{array}{l}82.88 \pm 7.32 \\
(68.70-94.10)\end{array}$ & $\begin{array}{l}92.49 \pm 4.22 \\
(85.50-101.5)\end{array}$ & $\begin{array}{l}0.003 \text { (I vs. II) } \\
\text { NS (I vs. III) } \\
0.0003 \text { (II vs. III) }\end{array}$ \\
\hline $\mathrm{RBC}, 10^{6} / \mu \mathrm{l}$ & $\begin{array}{l}3.54 \pm 0.54 \\
(2.43-4.31)\end{array}$ & $\begin{array}{l}4.01 \pm 0.85 \\
(2.23-5.21)\end{array}$ & $\begin{array}{l}4.55 \pm 0.50 \\
(3.78-5.63)\end{array}$ & $\begin{array}{l}\text { NS (I vs. II) } \\
<0.0001 \text { (I vs. III) } \\
0.028 \text { (II vs. III) }\end{array}$ \\
\hline WBC, $10^{3} / \mu \mathrm{l}$ & $\begin{array}{l}10.79 \pm 3.52 \\
(6.10-20.58)\end{array}$ & $\begin{array}{l}7.16 \pm 2.19 \\
(3.05-10.48)\end{array}$ & $\begin{array}{l}5.85 \pm 1.13 \\
(3.80-8.33)\end{array}$ & $\begin{array}{l}0.003 \text { (I vs. II) } \\
<0.0001 \text { (I vs. III) } \\
0.032 \text { (II vs. III) }\end{array}$ \\
\hline
\end{tabular}

Results are reported as mean \pm standard deviation (range).

Abbreviations: BMI - body mass index, HCT - hematocrit, HGB - hemoglobin, MCV - mean corpuscular volume, NS - nonsignificant, RBC - red blood cells, WBC - white blood cells, \%FM - body fat percentage

(\%FM). \%FM was significantly higher in the control group compared both with patients with ACD and those with IDA (TABLE 1).

The hematological parameters are shown in TABLE 1. As expected, hemoglobin, hematocrit, and erythrocyte count in both subgroups were significantly lower than in the control group. However, there was no difference in these parameters between patients with IDA and those with ACD. Moreover, patients with ACD had the highest white blood cell count among all groups. The mean corpuscular volume (MCV) in patients with IDA was significantly lower than that observed in patients with ACD and controls. There was no significant difference in the MCV between patients with ACD and controls (91.52 fl vs. $92.49 \mathrm{fl}$; $P=0.06)$.

We demonstrated that serum prohepcidin concentrations were significantly lower in elderly patients with anemia (both ACD $[196.59 \mathrm{ng} / \mathrm{ml}]$ and IDA [230.16 ng/ml]) compared with controls (292.18 ng/ml) (TABLE 2). However, no significant difference was observed between the subgroups of patients with IDA and those with ACD $(P=0.3456)$. Moreover, the 2 subgroups did not differ significantly in serum iron, sTfR, and EPO. In both subgroups, serum iron concentrations were significantly lower compared with the control group. Patients with ACD had significantly lower levels of TIBC compared with patients with IDA and controls. The serum ferritin concentration in ACD patients $(186.33 \mathrm{ng} / \mathrm{ml})$ was almost 20-fold higher compared with patients with IDA (9.18 ng/ml, $P<0.0001)$ and about 4-fold higher than in the control group $(42.62 \mathrm{ng} / \mathrm{ml}$, $P<0.0001$ ) (TABLE 2). Furthermore, CRP and IL-6 concentrations in the group of patients with $\mathrm{ACD}$ were significantly higher compared with patients with IDA and controls (TABLE 2).

There was a significant positive correlation between prohepcidin and ferritin in patients with ACD $(r=0.55, P<0.03)$. In patients with IDA, there was a negative correlation between prohepcidin and IL-6 $(r=-0.58, P=0.047)$ and a positive correlation with $\mathrm{WBC}(r=0.6573, P=0.02)$. In the control group, the serum prohepcidin level did not correlate with any hematological and iron parameters or inflammatory markers.

DISCUSSION The differential diagnosis of IDA and ACD in elderly patients is often difficult because of the lack of good differentiating biochemical indicators (with high sensitivity and specificity). Each of the routine biochemical markers 
TABLE 2 Iron metabolism parameters in patients with anemia of chronic disease and iron deficiency anemia

\begin{tabular}{|c|c|c|c|c|}
\hline \multirow[t]{2}{*}{ Parameter } & \multicolumn{2}{|c|}{ Study groups } & \multirow{2}{*}{$\begin{array}{l}\text { Control group } \\
\text { no anemia } \\
\text { III }(n=26)\end{array}$} & \multirow[t]{2}{*}{$P$} \\
\hline & $\begin{array}{l}\text { anemia of chronic disease } \\
I(n=26)\end{array}$ & $\begin{array}{l}\text { iron-deficiency anemia } \\
\text { II }(n=13)\end{array}$ & & \\
\hline prohepcidin, & 196.59 & 230.16 & 292.18 & NS (I vs. II) \\
\hline $\mathrm{ng} / \mathrm{ml}$ & $165.4 ; 231.6$ & $198.4 ; 241.1$ & $257.8 ; 335.8$ & $\begin{array}{l}0.0002 \text { (I vs. III) } \\
0.0277 \text { (II vs. III) }\end{array}$ \\
\hline iron, $\mu \mathrm{g} / \mathrm{dl}$ & $\begin{array}{l}22.55 \\
16.55 ; 37.20\end{array}$ & $\begin{array}{l}30.75 \\
13.35 ; 38.95\end{array}$ & $\begin{array}{l}81.60 \\
70.00 ; 92.00\end{array}$ & $\begin{array}{l}\text { NS (I vs. II) } \\
<0.0001 \text { (I vs. III) } \\
<0.0001 \text { (II vs. III) }\end{array}$ \\
\hline $\mathrm{sTfR}, \mu \mathrm{g} / \mathrm{ml}$ & $\begin{array}{l}2.27 \\
1.47 ; 3.03\end{array}$ & $\begin{array}{l}2.29 \\
1.77 ; 6.39\end{array}$ & $\begin{array}{l}1.56 \\
1.11 ; 2.03\end{array}$ & $\begin{array}{l}\text { NS (I vs. II) } \\
\text { NS (I vs. III) } \\
0.0165 \text { (II vs. III) }\end{array}$ \\
\hline $\mathrm{TIBC}, \mu \mathrm{g} / \mathrm{dl}$ & $\begin{array}{l}171.41 \\
130.20 ; 212.00\end{array}$ & $\begin{array}{l}309.01 \\
274.64 ; 333.51\end{array}$ & $\begin{array}{l}257.00 \\
229.0 ; 337.8\end{array}$ & $\begin{array}{l}<0.0001 \text { (I vs. II) } \\
<0.0001 \text { (I vs. III) } \\
\text { NS (II vs. III) }\end{array}$ \\
\hline ferritin, $\mathrm{ng} / \mathrm{ml}$ & $\begin{array}{l}186.33 \\
109.01 ; 332.76\end{array}$ & $\begin{array}{l}9.18 \\
2.24 ; 24.51\end{array}$ & $\begin{array}{l}42.62 \\
31.66 ; 75.50\end{array}$ & $\begin{array}{l}<0.0001 \text { (I vs. II) } \\
<0.0001 \text { (I vs. III) } \\
0.0002 \text { (II vs. III) }\end{array}$ \\
\hline EPO, U/I & $\begin{array}{l}12.89 \\
7.48 ; 17.28\end{array}$ & $\begin{array}{l}8.54 \\
4.79 ; 33.06\end{array}$ & $\begin{array}{l}4.91 \\
3.76 ; 8.64\end{array}$ & $\begin{array}{l}\text { NS (I vs. II) } \\
0.0009 \text { (I vs. III) } \\
\text { NS (II vs. III) }\end{array}$ \\
\hline $\mathrm{CRP}, \mathrm{mg} / \mathrm{l}$ & $\begin{array}{l}80.75 \\
45.15 ; 124.0\end{array}$ & $\begin{array}{l}5.50 \\
3.19 ; 7.40\end{array}$ & $\begin{array}{l}3.19 \\
3.00-5.00\end{array}$ & $\begin{array}{l}<0.0001 \text { (I vs. II) } \\
<0.0001 \text { (I vs. III) } \\
0.047 \text { (II vs. III) }\end{array}$ \\
\hline IL-6, pg/ml & $\begin{array}{l}12.20 \\
1.95 ; 15.99\end{array}$ & $\begin{array}{l}0.17 \\
0.00 ; 2.19\end{array}$ & $\begin{array}{l}0.10 \\
0.00 ; 1.11\end{array}$ & $\begin{array}{l}0.018 \text { (I vs. II) } \\
<0.0001 \text { (I vs. III) } \\
\text { NS (II vs. III) }\end{array}$ \\
\hline
\end{tabular}

Results are reported as medians $(01 ; 03)-25$ th and 75 th percentiles.

Abbreviations: CRP - C-reactive protein, EPO - erythropoietin, IL-6 - interleukin 6, sTfR - soluble transferrin receptor, TIBC - total iron-binding capacity, others - see TABLE 1

(such as transferrin saturation, CRP, ferritin, or transferrin receptor) has disadvantages, especially in the context of the older population. ${ }^{10,26-28}$ In contrast to the increased hepcidin levels in $\mathrm{ACD},{ }^{22,23,28,29}$ the classic IDA in humans is associated with low hepcidin expression. ${ }^{30,31}$ This makes hepcidin a potential marker discriminating between IDA and ACD.

In the present paper, we examined the usefulness of measuring prohepcidin levels in the differentiation of IDA from ACD and compared prohepcidin with the traditional parameters of the iron status. We also analyzed the associations between prohepcidin levels and hematological, biochemical, and inflammatory parameters in both types of anemia. Our data showed that circulating prohepcidin levels in patients with ACD were similar to those observed in the group of patients with IDA, and the difference between the groups was not statistically significant.

Our findings are in line with the recent observations of Dallalio et al., ${ }^{32}$ who reported that hepcidin levels, measured by Western blotting, were approximately the same in the 3 different types of anemia. However, another study, which analyzed urinary hepcidin levels, ${ }^{31}$ reported contradictory results. The authors analyzed 2 types of anemia. The first group consisted of patients with ACD and inflammation diagnosed on the basis of a clinical interview and elevated ferritin levels. The second group included patients with sideropenic anemia. The urinary concentration of hepcidin in patients with anemia of inflammation was higher compared with individuals with IDA. ${ }^{31}$ The discrepancies between the results could be due to the wide range of diagnostic methods used for the quantification of hepcidin and prohepcidin in different biological materials.

The analysis of the correlations provided interesting results. The positive correlation between prohepcidin and ferritin $(r=0.5536, P=0.0323)$ was observed in the group of patients with ACD. This finding is consistent with those reported by Małyszko et al., ${ }^{29}$ Dallalio et al., ${ }^{32}$ Nemeth et al.,, and Ferrucci et al. ${ }^{33}$ and seems to confirm the postulated role of hepcidin in the pathomechanism of ACD and inflammation. As expected, our comparative analysis revealed that patients with ACD had significantly higher levels of ferritin, CRP, and IL-6 compared with patients with IDA. These findings are consistent with the observations by Artz et $\mathrm{al}^{3{ }^{34}}$ In the group of patients with IDA, we observed a strong positive correlation between serum prohepcidin and leukocyte count $(r=0.66$, 
$P=0.02)$. However, it should be noted that WBC in this subgroup was in the reference range. Research findings and clinical observations suggest that patients with iron deficiency are more susceptible to infections due to decreased immunity. Iron plays an important role in the maturation, activation, and proliferation of lymphocytes. ${ }^{35,36}$ Peyssonnaux et al. ${ }^{37}$ revealed that bacteria-activated macrophages and granulocytes are capable of hepcidin synthesis. The correlation between prohepcidin and leukocyte count observed in our study confirms the significant role of prohepcidin in nonspecific immunity. ${ }^{17,18,38}$ Furthermore, an inverse correlation between prohepcidin and IL-6 ( $r=-0.58, P=0.047)$ was observed in the group of patients with IDA. These findings differ from the results of biological and human studies, which have revealed hepcidin to be type II acute-phase protein. ${ }^{21,31,39-44}$

Ferrucci et al. ${ }^{33}$ examined the association between urinary hepcidin levels, proinflammatory markers, and anemia in older persons. The authors found that IL-6 and CRP levels were associated with anemia and low iron status. However, they were not associated with higher urinary hepcidin..$^{33}$ Moreover, the authors suggested that increased hepcidin synthesis occurs only in overt inflammation. ${ }^{33}$ On the basis of the presented findings, it can be concluded that the regulation of hepcidin expression in the analyzed types of anemia is mediated by different mechanisms. Interestingly, both in ACD and IDA, the hepcidin level did not correlate with the indices of iron status (that is, iron, erythropoietin, saturation of transferrin), which are important determinants of hepcidin regulation.

It should be noted that the majority of studies dealing with the regulation of hepcidin expression were conducted on in-vitro cell cultures or in animal models. ${ }^{21,31,42-44}$ Only few clinical studies addressing the problem in question did not analyze the levels of hepcidin expression in real clinical conditions, but rather in experimentally induced states. ${ }^{43,45,46}$ Moreover, in view of the recent findings on the relationship between the degree of body adiposity and elevated expression and serum level of hepcidin, ${ }^{47-50}$ future studies should consider the potential effect of the nutritional status on circulating hepcidin levels. It is likely that the coexistence of obesity and anemia can limit the value of hepcidin in the differential diagnosis of anemia.

Numerous studies demonstrated that ferritin is more useful than other parameters in differentiating IDA form ACD. According to our study, ferritin levels were almost 20-fold higher in ACD compared with IDA. Ferritin, together with TIBC, IL-6, and CRP, provides the most useful information on the size of the iron pool as well as the stage of the inflammatory process. The major drawback of measuring serum ferritin to identify IDA is that the normal levels may be observed despite iron deficiency in numerous clinical conditions that are common in hospitalized and elderly patients (for example, infections, rheumatic disorders, malignancy, and other chronic illnesses). Thus, ferritin is of limited diagnostic value in elderly patients.

The sTfR assay has been suggested as a sensitive test for iron deficiency in older people. The sTfR concentration increases with iron deficiency but is not affected by acute or chronic inflammatory diseases. ${ }^{10,26-28}$ However, Chua et al. ${ }^{28}$ and Wians et al. ${ }^{51}$ showed that STfR is comparable to ferritin in diagnosing IDA in elderly patients. Our study also showed no usefulness of sTfR in the differential diagnosis of anemia in this patient group. Plasma sTfR concentrations in patients with ACD were similar (and did not show any statistical difference) to the concentrations observed in patients with IDA. Moreover, it has been demonstrated that both serum ferritin and sTfR increase with age. This limits the use of these parameters as iron status markers in elderly patients. ${ }^{10,26,27}$

The results of our preliminary study do not support the assumption that prohepcidin can be a useful laboratory parameter in the differential diagnosis of ACD and IDA in elderly patients. However, we cannot exclude that the active hormone, hepcidin, demonstrates such a discriminatory potential. An improved assay that measures serum hepcidin is now available ${ }^{40}$ and should be used to confirm these results. In addition, future studies should be conducted on a larger study group. Moreover, in some cases, ACD and IDA may coexist. For this reason, including the third subgroup with coexisting IDA and ACD would help to answer the question of whether prohepcidin/hepcidin is useful in the differentiation of IDA from ACD and IDA/ACD.

In conclusion, the results of our study indicate that serum prohepcidin has limited differential diagnostic value and does not help distinguish between IDA and ACD in elderly patients.

\section{REFERENCES}

1 Woodman R, Ferrucci L, Guralnik J. Anemia in older adults. Curr Opin Hematol. 2005; 12: 123-128.

2 Vanasse GJ, Berliner N. Anemia in elderly patients: an emerging problem for the 21st century. Hematology Am Soc Hematol Educ Program. 2010; 271-275.

3 Guralnik JM, Eisenstaedt RS, Ferrucci L, et al. Prevalence of anemia in persons 65 years and older in the United States: evidence for a high rate of unexplained anemia. Blood. 2004; 104: 2263-2268.

4 Guralnik JM, Ershler WB, Schrier SL, et al. Anemia in the Elderly: A Public Health Crisis in Hematology. Hematology. 2005; 1: 528-532.

5 Fleming RE, Sly WS. Hepcidin: a putative iron-regulatory hormone relevant to hereditary hemochromatosis and the anemia of chronic disease. PNAS. 2001; 98: 8160-8162.

6 De Domenico I, Zhang TY, Koening CL, et al. Hepcidin mediates transcriptional changes that modulate acute cytokine-induced inflammatory responses in mice. J Clin Invest. 2010; 120: 2395-2405

7 Ershler WB. Biological interactions of aging and anemia - a focus on cytokines. J Am Geriatr Soc. 2003; 51: 18-21.

8 Gabrilove J. Anemia and the elderly: clinical considerations. Best Pract Res Clin Haematol. 2005; 18: 417-422.

9 Ania BJ, Suman VJ, Fairbanks VF, et al. Incidence of anemia in older people: an epidemiologic study in a well defined population. J Am Geriatr Soc. 1997; 45: 825-831.

10 Balducci L, Hardy CL, Lyman GH. Hematopoietic growth factors in the older cancer patient. Curr Opin Hematol. 2001; 8: 170-187. 
11 DiMaria-Ghalili RA, Amella E. Nutrition in Older Adults: Intervention and assessment can help curb the growing threat of malnutrition. AJN. 2005; 105: 40-50.

12 Young VR. Macronutrient needs in the elderly. Nutr Rev. 1992; 50: 454-462.

13 Baccin AC, Lazzaretti LL, Brandao VDM, et al. Oxidative stress in old er patients with iron deficiency anaemia. J Nutr Health Aging. 2009; 13 666-670.

14 Kaldara-Papatheodorou EE, Terrovitis JV, Nanas JN. Anemia in hear failure: should we supplement iron in patients with chronic heart failure? $\mathrm{Po}$ Arch Med Wewn. 2010; 120: 354-360.

15 Stompór T, Olszewski A, Kierzkowska I. Can we prolong life of patients with advanced chronic kidney disease: what is the clinical evidence? Po Arch Med Wewn. 2011;121: 88-93.

16 Guyatt GH, Patterson C, Ali M, et al. Diagnosis of iron-deficiency anemia in the elderly. Am J Med. 1990; 88: 205-209.

17 Krause A, Neitz S, Magert HJ, et al. LEAP-1, a novel highly disulfide-bonded human peptide, exhibits antimicrobial activity. FEBS Lett. 2000 480: $147-150$

18 Park $\mathrm{CH}$, Valore $\mathrm{EV}$, Waring $\mathrm{AJ}$, et al. Hepcidin, a urinary antimicrobial peptide synthesized in the liver. J Biol Chem. 2001; 276: 7806-7810.

19 Knutson MD, Oukka M, Koss LM, et al. Iron release from macrophag es after erythrophagocytosis is up-regulated by ferroportin 1 overexpression and down-regulated by hepcidin. PNAS. 2005; 102: 1324-1328.

20 Nemeth E, Tuttle MS, Powelson J, et al. Hepcidin Regulates Cellular Iron Efflux by Binding to Ferroportin and Inducing Its Internalization. Science. 2004; 306: 2090-2093.

21 Nicolas G, Chauvet C, Viatte $L$, et al. The gene encoding the iron regulatory peptide hepcidin is regulated by anemia, hypoxia, and inflammation. $\mathrm{J}$ Clin Invest. 2002; 110: 1037-1044.

22 Domenico I, Ward DM, Kaplan J. Hepcidin regulation: ironing out the details. J Clin Invest. 2007; 117: 1755-1758.

23 Pietrangelo $A$, Dierssen $U$, Valli $L$, et al. STAT3 is required for IL-6-gp130-dependent activation of hepcidin in vivo. Gastroenterology. 2007; 132: 294-300.

24 Verga Falzacappa MV, Spasic MV, Kessler R, et al. STAT-3 mediates hepatic hepcidin expression and its inflammatory stimulation. Blood. 2007; 109: 353-358

25 Balducci L. Epidemiology of Anemia in the Elderly: Information on Diag nostic Evaluation. J Am Geriatr Soc. 2003; 51: 2-9.

26 Casale G, Bonora C, Migliavacca A, et al. Serum ferritin and aging. Age Ageing. 1981; 10: 119-122.

27 Tull Kl, Hirani V, Ali A, et al. Impact of different diagnostic thresholds and the anaemia-ferritin-transferrin receptor model on the prevalence of anaemia and impaired iron status in older people. Age Ageing. 2009; 38: 609-613.

28 Chua E, Clague JE, Sharma AK, et al. Serum transferrin receptor as say in iron deficiency anaemia and anaemia of chronic disease in the elderly. $0 \mathrm{~J}$ Med. 1999; 92: 587-594.

29 Małyszko J, Koc-Żorawska E, Levin-laina N. New parameters in iron metabolism and functional iron deficiency in patients on maintenance hemodialysis. Pol Arch Med Wewn. 2012; 122: 537-542.

30 Cheng PP, Jiao XY, Wang XH, et al. Hepcidin expression in anemia of chronic disease and concomitant iron-deficiency anemia. Clin Exp Med. 2011; 11: 33-42.

31 Nemeth $\mathrm{E}$, Valore EV, Territo $\mathrm{M}$, et al. Hepcidin, a putative mediato of anemia of inflammation, is a type II acute-phase protein. Blood. 2003 101: 2461-2463.

32 Dallalio G, Fleury T, Means RT. Serum hepcidin in clinical specimens Br J Haematol. 2003, 122: 996-1000.

33 Ferrucci L, Semba RD, Guralnik JM, et al. Proinflammatory state, hep cidin, and anemia in older persons. Blood. 2010; 115: 3810-3816.

34 Artz AS, Fergusson D, Drinka PJ, et al. Mechanisms of unexplained anemia in the nursing home. J Am Geriatrics Soc. 2004; 52: 423-427.

35 Brock JH, Mulero V. Cellular and molecular aspects of iron and immune function. Proc Nutr Soc. 2000; 59: 537-540.

36 Małyszko J, Levin-laina N, Myśliwiec M, et al. Iron metabolism in solid-organ transplantation: how far are we from solving the mystery? Pol Arch Med Wewn. 2012; 122: 504-511.

37 Peyssonnaux C, Zinkernagel AS, Datta V, et al. TLR4-dependent hepcidin expression by myeloid cells in response to bacterial pathogens. Blood. 2006; 107: 3727-3732

38 Ganz T. The role of hepcidin in iron sequestration during infections and in the pathogenesis of anemia of chronic disease. Isr Med Assoc J.2002 4: 1043-1045

39 Roe MA, Collings $R$, Dainty JR, et al. Plasma hepcidin concentrations significantly predict interindividual variation in iron absorption in healthy men. Am J Clin Nutr. 2009; 89: 1088-1091.

40 Ganz T, Olbina G, Girelli D, et al. Immunoassay for human serum hepcidin. Blood. 2008; 112: 4292-4297.
41 Tan TC, Crawford DH, Franklin ME, et al. The serum hepcidin:ferritin ratio is a potential biomarker for cirrhosis. Liver Int. 2012; 32: 1391-1399.

42 Lee $\mathrm{P}$, Peng $\mathrm{H}$, Gelbart $\mathrm{T}$, et al. Regulation of hepcidin transcription by interleukin-1 and interleukin-6. Proc Natl Acad Sci. 2005; 102: 1906-1910.

43 Nemeth E, Rivera S, Gabayan V, et al. IL-6 mediates hypoferremia of in flammation by inducing the synthesis of the iron regulatory hormone hepcidin. J Clin Invest. 2004; 113: 1271-1276.

44 Pigeon C, llyin G, Courselaud B, et al. A new mouse liver-specific gene, encoding a protein homologous to human antimicrobial peptide hepcidin, is overexpressed during iron overload. J Biol Chem. 2001; 276: 7811-7819.

45 Benedict C, Ghio AJ, Gehring H, et al. Transient hypoxia and downregulation of circulating prohepcidin concentrations in healthy young men. Haematologica. 2007; 92: 125-126.

46 Kemna EHJM, Pickkers $P$, Nemeth E, et al. Time-course analysis of hepcidin, serum iron, and plasma cytokine levels in humans injected with LPS. Blood. 2005; 106: 1864-1866.

47 Bekri S, Gual P, Anty R, et al. Increased adipose tissue expression of hepcidin in severe obesity is independent from diabetes and NASH. Gastroenterology. 2006; 131: 691-693.

48 Chung B, Matak P, McKie AT, et al. Leptin Increases the Expression of the Iron Regulatory Hormone Hepcidin in HuH7 Human Hepatoma Cells. J Nutr. 2007; 137: 2366-2370.

49 Przybyszewska J, Żekanowska E, Kedziora-Kornatowska K, et al. Prohepcidin and iron metabolism parameters in the obese elderly patients with anemia. J Nutr Health Aging. 2011; 15: 259-264.

50 del Giudice EM, Santoro N, Amato A, et al. Hepcidin in obese children as a potential mediator of the association between obesity and iron deficiency. J Clin Endocrinol Metab. 2009; 94: 5102-5107.

51 Wians FH Jr, Urban JE, Keffer JH, et al. Discriminating between iron deficiency anemia and anemia of chronic disease using traditional indices of iron status vs transferrin receptor concentration. Am J Clin Pathol. 2001; 115: $112-118$ 


\title{
Stężenie surowiczej prohepcydyny oraz innych parametrów gospodarki żelazowej u pacjentów w wieku podeszłym z niedokrwistością chorób przewlekłych oraz niedokrwistością z niedoboru żelaza
}

\author{
Justyna Przybyszewska', Ewa Żekanowska², Kornelia Kędziora-Kornatowska³, \\ Joanna Boinska², Roman Cichon', Katarzyna Porzych ${ }^{3}$ \\ 1 Katedra i Zakład Żywienia i Dietetyki, Uniwersytet Mikołaja Kopernika, Collegium Medicum im. Ludwika Rydygiera w Bydgoszczy \\ 2 Katedra Patofizjologii, Zakład Zaburzeń Hemostazy, Uniwersytet Mikołaja Kopernika, Collegium Medicum im. Ludwika Rydygiera w Bydgoszczy \\ 3 Katedra i Klinika Geriatrii, UUniwersytet Mikołaja Kopernika, Collegium Medicum im. Ludwika Rydygiera w Bydgoszczy
}

\section{SŁOWA KLUCZOWE}

niedokrwistość chorób przewlekłych, niedokrwistość z niedoboru żelaza, prohepcydyna
Adres do korespondencji: dr med. Justyna Przybyszewska, Katedra i Zakład Żywienia i Dietetyki, Uniwersytet Mikołaja Kopernika Collegium Medicum im. Ludwika Rydygiera, ul. Dębowa 3, 85-626 Bydgoszcz, tel.: 52-585-54-03, fax: 52-585-54-00, e-mail:.j.szwarc@wp.pl Praca wpłynęła: 18.10.2012. Przyjęta do druku: 08.01.2013 Publikacja online: 08.01.2013. Nie zgłoszono sprzeczności interesów.

Pol Arch Med Wewn. 2013; 123 (3): 105-111

Copyright by Medycyna Praktyczna Kraków 2013

\section{STRESZCZENIE}

WPROWADZENIE Rozpoznanie niedokrwistości z niedoboru żelaza (iron deficiency anemia - IDA) w kontekście niedokrwistości chorób przewlekłych (anemia of chronic disease - ACD) u pacjentów w wieku podeszłym jest często trudne ze względu na istnienie wielu zaburzeń. Najnowsze badania wykazują, że oznaczenie hepcydyny (w połączeniu z istniejącymi metodami diagnostycznymi) może prawdopodobnie pomóc $w$ diagnostyce różnicowej IDA i ACD.

CELE Celem badania była ocena przydatności surowiczej prohepcydyny w diagnostyce różnicowej IDA oraz ACD u pacjentów w podeszłym wieku.

PACJENCI I METODY Do badań zakwalifikowano 65 osób w wieku $\geq 65$ lat: 26 pacjentów z ACD, 13 pacjentów z IDA oraz 26 osób w podobnym przedziale wiekowym jako grupę kontrolną. Za pomocą dostępnych komercyjnych testów immunoenzymatycznych mierzono stężenie: prohepcydyny, ferrytyny, rozpuszczalnego receptora transferyny, erytropoetyny i interleukiny 6 (IL-6). Dodatkowo przy użyciu standardowych metod laboratoryjnych oznaczono morfologię krwi, całkowitą zdolność wiązania żelaza (total iron-binding capacity - TIBC) oraz poziom żelaza, transferyny i białka C-reaktywnego (CRP).

WYNIKI Stężenie prohepcydyny u pacjentów z ACD $(196,59 \mathrm{ng} / \mathrm{ml})$ było podobne do stężenia obserwowanego u pacjentów z IDA $(230,16 \mathrm{ng} / \mathrm{ml})(\mathrm{p}=0,35)$. Pacjenci z ACD mieli znacząco niższy poziom TIBC niż pacjenci z IDA ( $p<0,0001$ ). Stężenie ferrytyny u pacjentów z ACD było prawie 20-krotnie większe w porównaniu z wartościami uzyskanymi w grupie chorych z IDA ( $p<0,0001)$. Stężenie CRP i IL-6 u pacjentów z ACD było istotnie większe niż u chorych z IDA.

WNıOSKI Wyniki badań wskazują na ograniczoną wartość surowiczej prohepcydyny w diagnostyce różnicowej IDA i ACD u osób w podeszłym wieku. 